IKONOMIKA: Journal of Islamic Economics and Business

Volume 3, No I (2018)

ISSN : 2527-3434 (PRINT) - ISSN: 2527-5I43 (ONLINE)

Page : $89-96$

\title{
Financial Performance Bank BNI Syariah Company
}

\author{
Diana Widhi Rachmawati \\ PGRI University of Palembang Accounting Lecturer \\ Dianawidhi72@yahoo.com
}

\begin{abstract}
PT Bank BNI Syariah, one of them working are a big banking company is almost covering all over the country until now looked at pretty good company asset which are owned, so author conduct research in the title "Financial Performance PT Bank BNI Syariah in Solvability Ratio". Financial Statement Analysis is aplication from tools and technical analysis financial report general aim and data to be related and estimation produce useful conclutions in business analysis. Financial Performance Analysis research used analysis methode is solvability ratio. General aim to give information finance performance PT Bank BNI Syariah development. Special goals is finance performance PT Bank BNI Syariah from Solvability Ratio". This Sample is: PT Bank BNI Syariah. Final result which is research obtained it says finance performance PT Bank BNI Syariah from Solvability Ratio quite solvable, because this three point inside it contained increased. This development hope PT Bank BNI Syariah, to be remain consistent with trying to do breakthrough a company goals
\end{abstract}

\section{Key Words : Financial Performance PT Bank BNI Syariah}

\section{A. INTRODUCTION}

Generally established with the authority to accept deposits of money, lend money and issue promissory notes or banknotes. The role of banks today is very dominant in the economi of society in Indonesia.. Almost every community economic activity is inseparable from the role of banks and other financial institutions outside the bank, in carrying out its activities, the bank offers a variety of products that contain activities supporting the economy of the community, ranging from services to combine of money remittance community or other services essentially facilitate the public to conduct business activities and everyday economy.

Received :May 05, 2018- Revised: May 05, 2018- Accepted :May 23, 2018

PGRI University of Palembang Accounting Lecturer

Email:Dianawidhi72@yahoo.com 
Some people themselves have unconsciouslyfelt dependent on the activities of the bank the conduct its economics activities ranging from shopping everyday to just for charging credit for his cell phone, this not just a trend in society, but it is the development of the times and technology and the development needs of society. In line with the development of the era, the bankng in Indonesia also experienced developments in addition to increasing the awareness of Indonesian people, especially Moeslim, to apply daily religious life so that sharia banking is formed.

From several syariah banking of Indonesia, writer take focus of research at Bank Syariah to see how financial performance PT BNI Syariah seen from solvency ratio ?

\section{B. THEORITICAL}

Kasmir (2003), Banks simply can be interpreted as a financial institution where the main activity is to collect funds from the community and channel the funds back in to the community and provide services other banks.

Santoso dan Susilo Triandoro (2006), The main function of the bank :

\section{Agent of Trust}

Trust is the key in the main basis of banking activities to raise funds from the community and channel them back into community

2. Agent of Development

Activities that enable people to invest, distribute and consume services whereall activities are not seperated from the use of money.

3. Agent of Srvice.

Offering other banking services such as remmitances, valuables, provision of bank guarantees and settelment of claims

Act number 2I of 2008 about sharia banking is a bank that runs business activities based on sharia principles or principles of Islamic law as stipulated in the fatwa of Indoniseian Ulema Council Gustani (20I4), The function of syariah bank is

I. Collecting and channelling public funds

2. Receive zakat funds, infaq, grants or other social funds and distribute them to zakat management organizations

3. Receive wakaf money and distribute it to the manager of wagf (nadzir) in accordance with the will of the giver of

Harahap (2009), Financial Report is an information medium that summarizes all activities for management, investors, banks, government and the general public. One of the most important tasks undertaken by management or 
investors after the end of the year is to analyze the company's financial statements with the purpose of broader and deeper information from financial statements.

Wild (2005), Financial Statement Analysis is the application of technical and analiss for general financial statements and data that discusses to produce and useful benefits.

Munawir (2004), There are two methods of analysis used by each financial report, namely:

I. Horizontal Analysis Perform analysis using financial statements for several periods or a few moments or a few moments, it will create new developments.

2. Vertical analysis is an analysis that only covers one period or one time only,by comparing between one post with another post in the financial statements Jumingan (2006), Performance is a form of achievement in the operational activities both in the aspects of finance, burden, fund raising costs and fund distribution, technological aspects, and aspects of human resources.

Mahmud (2003), Financial performance measures include the following ratios:

I. Liquidity Ratio measures a company's ability to meet short-term requirements or the ability of a company to achieve its obligations when billed.

2. Any measuring Activity ratio uses an asset by looking at the activity level

3. Solvency ratios measure the extent to which firms meet their long-term liabilities

4. Profitability ratio measures the company's ability to generate profit (profitability)

5. Market Ratio measures the development of corporate value relative to market value

Variables are all whatever in the form of what is set by the researcher to be studied so that in obtaining information about it, then drawn the conclusion. The variable as an attribute of a person or object that has "variation" between one person to another or another object. (Sugiyono, 2012: 60).

Again, variable variables are the object of research, or what is the focus of a research (Arikunto, 2010: 16I)

Based on the opinion above, the variables in this study are:

(X) dependent variable: Financial Results of PT Bank BNI Syariah. When Viewed From the Corner of Solvency Ratio. 
Based on the above variables, can be defined in this study are: Financial Performance Results PT Bank BNI Syariah. When Viewed From the Corner of Solvency Ratio.

If Viewed From a Solvency Ratio Point is an overall measurement, management, interpretation, and consideration activity for making a decision on the Solvency Ratio level of PT Bank BNI Syariah

Population is a generalization area consisting of: object / subject having certain quality and characteristic determined by researcher to be studied and then drawn its conclusion (Sugiyono 2012: II7). So the population in this study for the subject is the researcher and the object is PT Bank BNI

The sample is part of the number and characteristics possessed by the population (Sugiyono 20I2: II8). In relation to the population in this study a little so this study uses population research, so that the sample is the entire population.

In this research the researcher use quantitative research method, quantitative research method is as research method based on philosophy of positivism, used to research on population or certain sample, sampling technique generally done by random, data pengungilan mengguanakan research instrument, quantitative data analysis / statistics with the aim to test the hypothesis that has been set. (Sugiyono 20I2: I4)

The method of research is the way of scientific research to obtain valid data with the purpose to be found, developed, and proven, a certain knowledge so that in turn can be used to understand, solve and anticipate problems in the field of education

In this research method the researcher uses an experimental method where the experimental method is useful to determine why a condition or event occurs. This experimental method is a research method to conduct experimental activities in order to obtain a result.

With this experimental method researchers deliberately generate the incidence of an event or circumstance, then examined how the consequences. In other words experiments are a way to find causal relationships, experiments are always done to see the effect of a treatment (Arikunto, 2010: 9)

This means that experiments are an experiment to examine an event or symptom that appears in certain conditions and at each symptom appears observed and controlled as closely as possible. So it can be known cause due to the emergence of these symptoms. 
In this study the researchers took samples of banking companies as an experiment to determine the financial performance of PT Bank BNI Syariah when viewed from the ratio of solvency.

Data collection techniques is the most strategic step in the research, because the main purpose of the research is to obtain data, without knowing the data collection techniques, the researchers will not get the data meet the established data standards (Sugiyono, 20I2: 308)

To get accurate data then the researchers collect data by using the method:

Documentation is to search data about things or variables in the form of notes, transcripts, books, newspapers, magazines, meeting minutes, leggers, agenda, etc. (Arikunto, 2010: 274).

According to Nasution (in Sugiyono 2012: 310) states that observation is the foundation of all science. Scientists can only work on data, ie facts about the world of reality gained through observation. The observation in this study contains three activities (indicators), namely visual activity, oral activity, mental activity and each each indicator contains three descriptor.

\section{METHODOLOGY}

Data analyst technique is a technique used to collect data that has been collected and classified in accordance with the purpose of research. Analysis is able to understand the subject matter in depth and compare the data and information.

\section{RESULTS AND DISCUSSION}

Financial ratios are figures derived from the results of a comparison of one financial statement post with other posts that have a relavan and significant relationship minsalnya, between debt and capital, between cash and total assets, and so forth. Here we have analyzed the financial statements of PT. BANK BNI

I. Total debt to total equity ratio

$$
\begin{aligned}
& =\frac{\text { Current Liabilities }+ \text { Long Term Liabities }}{\text { owner's equity }} \times 100 \% \\
& =\frac{513,778+513,778}{21,077} \times 100 \% \\
& =4,875,3
\end{aligned}
$$


Financial Performance Bank Bni Syariah Company

(Diana Widhi Rachmawati)

2. Long term debt to equity ratio

$$
\begin{aligned}
& =\frac{\text { long term liabilities }}{\text { owner's equity }} \times 100 \% \\
& =\frac{513,778}{21,077} \times 100 \% \\
& =2,437,7
\end{aligned}
$$

3. Total debt to asset ratio

$$
\begin{aligned}
& =\frac{\text { current liabilities }+ \text { short term liabilities }}{\text { owner's equity }} \times 100 \% \\
& =\frac{513,778+513,788}{21,077} \times 100 \% \\
& =4,875,3
\end{aligned}
$$

\begin{tabular}{|c|c|c|c|}
\hline \multicolumn{2}{|c|}{ Ratio Name } & \multirow{2}{*}{ Number } & \multirow{2}{*}{ Kode } \\
\hline Core & Sub & & \\
\hline \multirow{3}{*}{$\begin{array}{l}\text { Solvability } \\
\text { Ratio }\end{array}$} & I. Debt to Asset Ratio & $4,88 \%$ & $\mathrm{~S}$ \\
\hline & 2. Debt to Equity Ratio & $2,44 \%$ & S \\
\hline & $\begin{array}{l}\text { 3. Long Term Debt to Equity } \\
\text { Ratio }\end{array}$ & $4,88 \%$ & $\mathrm{~S}$ \\
\hline
\end{tabular}

Table I

Analysis Results

Where in this solvency ratio can be said also good because solvency level good ratio of debt, ratio of capital and long term debt still above I\% mean PT Bank BNI Syariah still able to finance operational for the period of several years ahead 


\section{E. CONCLUSION}

This solvency ratio can be said good solvency level.The company can reserve the capital or increase the existingcapital because although fairly good, but still thin the difference that makes it possible vulnerable to the company can solvabel

\section{REFERENCES}

Antonio, Muhamad Syafii. 200I. Bank Syariah, dari Teori ke Praktik. Jakarta: Tazkia Cendekia. Yogyakarta: UGM Press

Arikunto, Suharsimi. 20I0. Prosedur Penelitian suatu Pendekatan Praktik. Jakarta: Rineka Cipta

2012. Prosedur Penelitian suatu Pendekatan Praktik. Jakarta: Rineka Cipta

2013. Prosedur Penelitian suatu Pendekatan Praktik. Jakarta:

Rineka Cipta

Djamarah,Bahri,Syaiful . 20I0. Strategi Pembelajaran Jakarta: Bumi Aksara.

Fakultas Keguruan dan Ilmu Pendidikan. 2015. Pedoman Penulisan Skripsi. Palembang: Universitas PGRI

Gustani, S.E.I.M.Ak.SAS., 20I4, Islamic Economics, https://gustani.blogspot.com Hamdani, 20I I. Strategi Belajar Mengajar. Bandung: Pustaka Setia.

Harahap, Sofyan Syafri. 2009. Analisis Kritis Atas Laporan Keuangan, Jakarta: PT RajaGrafindo

Https://id.m.wikipedia.org

Https://www.ojk.go.id

Ikit, S.E., M.E.I., 2017, Manajemen Dana Bank Syariah, Yogyakarta: Gava Media Jumingan, 20I I. Analisis Laporan Keuangan. Jakarta : Bumi Aksara

Jurnal Penelitian bank syariah vs bank konvensional, https://www.bi.go.go.id

LPPKMK Universitas PGRI. 20I2. Pedoman Penulisan Penelitian Dosen. Palembang: Puslit Universitas PGR Palembang

Munawir, Drs. S. Analisa Laporan Keuangan, Yogyakarta : Liberty

Purwanto, Ngalim. 2013. Prinsip-prinsip dan Teknik Evaluasi Pengajaran.

Bandung: PT. Remaja Rosdakarya

Purnamasari, F., \& Darmawan, A. (2017). Islamic Banking and Empowerment of Small Medium Enterprise. Etikonomi, I6(2), 22I-230. 
Financial Performance Bank Bni Syariah Company

(Diana Widhi Rachmawati)

Yaya, Rizal, Aji Erlangga M dan Ahim Abdurahim. 20I4. Akuntansi Perbankan Syariah Teori dan Praktik Kontemporer,Jakarta: Salemba Empat 